\title{
Corruption and EU Institutions: The Italians' Opinion
}

\section{Vincenzo Memoli}

Department of Political and Social Sciences

Università degli Studi di Catania

Via Vittorio Emanuele II 8

95131 Catania (Italy)

Tel. +39095 70305232

Fax +39 095-70305246

memoli@unict.it

\author{
Alessandro Pellegata \\ Department of Social and Political Sciences \\ Università degli studi di Milano \\ Via conservatorio 7 \\ 20122 Milano (Italy) \\ Tel. +390250321221 \\ Fax +390250321240 \\ alessandro.pellegata@unimi.it
}

Paper published in Perspectives on European Politics and Society 15(2): 165-182.

Available at:

https://www.tandfonline.com/doi/abs/10.1080/15705854.2014.885771 ?journalCode $=r p$ ep20\#.UzGInYXdfLk 


\begin{abstract}
Corruption is unanimously recognized an endemic pathology of the Italian political system. Even after the "Tangentopoli" scandals that broke down the Prima Repubblica and rapidly changed the partisan configuration, corruption remains one of the most relevant problems that affects the public sector. The different governments that came in succession do not seem to have achieved significant results in constraining corruption. Italian citizens perceive institutions as corrupt and are increasingly disenchanted about politics. But what is the opinion of the Italians about the role of EU institutions in facing the problem of corruption? The purpose of this paper is to analyze the perceptions of the Italian citizens about the spread of corruption within EU institutions and their potential role in preventing and fighting corruption in their country. In line with a relevant piece of literature we expect that citizens attitudes toward EU in relation to the problem of corruption are mainly driven by their perceptions of the domestic national context. Taking advantage of data gathered from Eurobarometer, and comparing the Italian and the European contexts, the paper shows that citizens' opinions about corruption within EU institutions are drawn by their perceptions at the national level. However, at the same time, citizens who express more negative evaluations of the performance at the national level tend to be more confident in the role played by EU in restraining corruption.
\end{abstract}

Keywords: Corruption; European Union; Italy; Political Support. 


\section{Corruption and EU Institutions: The Italians' Opinion}

\section{Introduction}

In the last fifteen years much has been written about the detrimental effects of corruption on the economic performance of countries (Knack and Keefer 1995; Mauro 1995), the quality of democracy (Kaufmann et al. 1999; Morlino 2004) and the citizens'support for political institutions (Mishler and Rose 2001; Anderson and Tverdova 2003). Among the consolidated democracies Italy presents one of the highest levels of corruption (see Figure 1 below). Corruption is unanimously recognized by the national and international institutions an endemic pathology of the Italian political system (see, for instance, Giampaolino 2011; Rigamonti 2013). In the early nineties a series of corruption scandals, identified with the name Tangentopoli, hit almost all the traditional parties unveiling a widespread and consolidated system of politicians malfeasance and illicit funding. As shown by Chang et al. (2010), during the eleventh Italian legislature (1992-1994), when Tangentopoli reached its peak, 35\% of Deputies were charged with serious corruption crimes and $69 \%$ of them lost their seats after the 1994 elections. As a consequence of Tangentopoli, Italy experienced a broad reconfiguration of the party system and an electoral reform. This is why 1994 elections, the first with the new mixed-member proportional representation system, was considered a turning point in the Italian political history, marking the transition to the so called Seconda Repubblica.

Even after Tangentopoli corruption remains one of the most serious problems affecting the public sector. Only few years after "Mani Pulite" (Clean Hands) inquiries, a nationwide judicial investigation into political corruption held in the early nineties and led by a Milan pool of prosecutors, the issue of corruption faded from the agenda of 
Italian politics. Corruption is still systemic and the different governments that came in succession do not seem to have achieved significant results in constraining it. As argued by Vannucci (2009), it seems rather that the increasing spread of corruption during the 2000s has been enhanced by the failure of anti-corruption policies and the approval of potentially corruption-enhancing measures. Nevertheless, this scenario is not characterized by a citizens' uncritical acceptance of the situation. As shown by Memoli (20013), as a consequence of continuous corruption scandals that hit the political class, both at the national and at the regional level, the citizens' confidence in the most important political institutions shows an impressive negative trend in the last decade. This attitude has been reflected by the unexpected result obtained in the legislative election held in February 2013 by the Movimento 5 Stelle, which most important keywords of its political campaign were the transparency of the decision-making process and the replacement of the corrupt political class of the Seconda Repubblica (Corbetta and Gualmini 2013).

However, while scholars and analysts have deeply studied the problem of corruption among Italian public officials, much less attention has been paid to the spread of this phenomenon within the institutions of the European Union. With the process of European integration and the adoption of Euro European Union is assuming an increasingly relevant role in setting the agenda of the member states' decisionmaking process. Even though mass public opinion on European Union, and in particular on the process of European integration, has been object of a plethora of studies since the seventies, very few researches focus on the problem of corruption within EU institutions.

The present paper aims to investigate the Italians' opinions on the relationship between corruption and European Union. On one side it analyzes the perceptions of the 
Italian citizens of the spread of corruption within EU institutions. On the other side, the study assesses the Italians' attitude about the potential role of the European Union in providing a solution for specific corruption cases.

According to a relevant piece of literature which stresses the political basis for support for European integration (Anderson 1998; Sanchez-Cuenca 2000), we hypothesize that citizens' opinions on the relationship between corruption and EU institutions are influenced by the perceptions of the spread of corruption in the domestic national context. However, there is no scholarly agreement about the direction of the relationship between the quality of national institutions and attitudes toward EU. For this reason we advance two research hypotheses. The first hypothesis postulates that the higher the citizens perceptions of corruption in domestic national context, the higher their perception of corruption within EU institutions. The second hypothesis instead postulates that the more citizens perceive their national institutions as corrupt, the more they trust the role played by the European Union in providing a solution for the problem of corruption. The argument underlying the first hypotheses assume that citizens fill their knowledge gap about EU institutions using the domestic context as a "proxy" (Anderson 1998). The logic that lies at the basis of the second hypothesis instead is the opposite, advancing that a kind of "substitution mechanism is in action (SanchezCuenca 2000).

The present study addresses this topic making use of the Eurobarometer 72.2 released in September-October 2009. In the first part of the paper we conduct a descriptive analysis which analyzes the level of corruption perceived by the Italian citizens within national and EU institutions and their trust in the European Union in contrasting corruption. The perceptions expressed by the Italian citizens are compared with the average level of perceived corruption in the European Union and other 
subareas of countries. In the second part of the paper we perform a multivariate analysis which aims to assess which factors determine the Italians' perceived level of corruption within EU institutions and their trust in the role of EU in providing a solution for corruption cases.

From the empirical results acquired emerges that Italian citizens' opinions on the spread of corruption within EU institutions are mainly drawn by their perceptions at the national level. However, at the same time, citizens that perceive corruption as more widespread at the national level tend to express higher level of confidence in a positive role played by EU institutions in providing a solution for corruption cases. The findings obtained looking at the Italian respondents are confirmed by analyses taken on larger samples which include citizens of the Mediterranean European countries and of all the twenty-seven EU member states.

In the next section we conduct a descriptive analysis that aims to show the perceptions of Italian and European citizens on the corruption within domestic and EU institutions as well as their trust in EU to provide a solution for corruption cases. In the third section we explain the theoretical framework adopted and the research hypotheses advanced and in the following one we describe the data and the variables used in the multivariate analysis. Then, we discuss the main empirical results obtained. Finally, in the last section we drawn the main conclusions of this study.

\section{Perceptions of Corruption and Trust in EU in Italy and in the European Union}

The Transparency International report (2012), which brings together the findings of 25 National Integrity Systems assessments carried out across Europe in 2011, argues that “... even those [political systems] usually considered to be the 'cleanest of the clean', have some deficits in their anti-corruption frameworks". Of course, there is a huge 
variation across the region with some integrity systems exhibiting more robust mechanisms than others. Scandinavian countries are unanimously recognized some of the cleanest countries across the world, whereas Southern and Eastern European countries present the highest levels of corruption among the advanced industrial democracies.

Figure 1 shows the trend of the average level of corruption across European Union member states (dotted line) and in Italy (continuous line) according to the Corruption Perceptions Index (CPI) developed by the global network Transparency International. CPI is a perceptions-based index developed relying upon expert surveys, which ranges between 0 and 10, with 0 indicating high level of perceived corruption and 10 indicating low corruption, and so more transparent and efficient institutions. ${ }^{1}$

Figure 1 about here

From 1995 (the first year in which CPI was released) until 2003 the average CPI score among EU member states was 7.50, indicating a quite appreciable level of institutionsal transparency. However, this score declines at 6.58 in 2004 in connection with the EU enlargement process to ten new member states. In fact, eight out of ten of the new member states were post-communist countries of eastern Europe, which were characterized by young and weak institutions (Zakaria 2013). The average level of corruption remained constant until 2007, when two other post-communist countries, Bulgaria and Romania, entered the Union and the CPI score declined at 6.51. These two countries are perceived by the experts as the most corrupt EU member states. Since

\footnotetext{
${ }^{1}$ For information and data on CPI see http://www.transparency.org/research/cpi/.
} 
2007 the CPI score slightly but continuously declined and in 2010 reached the value of 6.30 .

As we can easily note from Figure 1, the corruption trend of Italy is characterized by a CPI score that is constantly much lower than the EU average value. After the corruption scandals of the Tangentopoli period (1992-1994) described above, the CPI score of Italy was in fact incredibly low (2.99), indicating that the experts evaluated Italy as a highly corrupt country. In the 1995 ranking of countries developed according to the CPI score, Italy occupied the $31^{\text {st }}$ position out of 39 . Then, apart from a decline between 1997 and 2000, CPI annual score of Italy increased almost always until 2001 when reached the value of 5.55. Nevertheless, since 2001 the perceived level of corruption within the Italian institutions started to decrease again, and this decline became particularly problematic after 2007. It is presumable that this decline has been fostered by the combination of several events, such as the constant political instability inside the majority coalition that supported the Prodi II government (2006-2008), also nourished by political scandals, and the persistent recession of the Italian economy. These factors, besides the effects of the international financial crisis that, since 2008, invested Europe, and in particular Southern countries such as Italy, Greece Spain and Portugal, generated instability and uncertainty which constituted a fertile ground for politicians' malfeasance. In 2010, the CPI score was 3.90, just one point more than the dramatic score obtained in 1995 after one of the most troubling period of Italy's democratic history, and 2.56 points less than the peak of 2001.

The alarming situation highlighted by the experts' surveys can be found also among common citizens, as confirmed by data gathered from Eurobarometer 72.2, released in September-October 2009. This Eurobarometer wave explores, among other issues, the perceptions of the European general public on the spread of corruption at 
different institutional levels, from the local to the EU one, and the citizens' opinion on the role played by different institutional bodies in preventing and fighting corruption. On average, $79.9 \%$ of European citizens consider corruption as a major problem in their country, and this value reach $84.5 \%$ among Italian citizens. This 5\% difference with the EU average level increases till $11 \%$ if we compare the percentage of Italian respondents who believe that corruption is a major problem with the average level of the fifteen older EU member states (73.4\%).

The graph reported in Figure 2 is obtained applying a Multiple Correspondence Analysis (MCA) to several information on corruption surveyed by the Eurobarometer. MCA allows us to reduce the wide range of variables considered here into a more limited number of factors. ${ }^{2}$ Then, using the SPAD_N software, we have explored the relationship among the indicators of corruption and other socio-economic and regional characteristics of the Italian respondents. The result is a bi-dimensional space with two factors that explain $55.9 \%$ of the total variance. ${ }^{3}$ In the graphical representation reported in Figure 2 these two factors correspond to the two axes. The first factor (horizontal axis) explains $43.9 \%$ of the total variance and the second factor (vertical axis) $12 \%$ of it.

\footnotetext{
${ }^{2}$ In statistical terms, the subjects of the analysis are arrays of contingency, whose elements indicate the number of times that the characteristics of two different sizes have been detected jointly. In the arrays rows and columns play similar roles, as they represent a breakdown of the whole data according to two magnitudes qualitative type, each in turn divided into a group of characteristics or modalities. The analysis aims to explain why the data matrix deviates from a position of homogeneity which occurs when the rows (or columns) are proportional. In this work the active variables - which contribute to the formation of the two axes factors - included in our MCA are 71. We did not consider the variables which modalities presented a frequency percentage less than 2 .

${ }^{3}$ Since eigenvalues obtained by MCA give a pessimistic evaluation of the variability explained by factorial axes, we have computed the variance considering only eigenvalues higher than $1 / \mathrm{k}$, where $\mathrm{k}$ is the number of variables used in the analysis (see Benzécri 1965; 1976).
} 
The distance of different modalities from the center of the two factorial axes tells us how much they contribute to the definition of the axes. ${ }^{4}$ The horizontal axis tells us the perceptions of how much widespread is corruption at different levels of government (local, regional and national level) and with reference to different figures of the public sector (politicians and bureaucrats). Moving from the left to the right of the horizontal axis means that the level of perceived corruption among citizens increases. The vertical axes refers instead to the citizens' reticence. Italian citizens that apparently do not have a view about the problem of corruption are located in the lower side of the graph, where we have a high no response rate. In the upper-left side instead are located those citizens who express an opinion on the spread of corruption in the public sector.

Figure 2 about here

From this descriptive analysis of the Italian scenario there are two important results that is worth to stress. The first is that citizens' perceptions of corruption at the different levels of governments tend to move together. Citizens who consider corruption as a major problem in their country think that it is widespread at the national level as well as in the regional and local institutions. Moreover, these citizens think that corruption is particularly diffuse especially among politicians and the police, as well as in the public health and the business sectors of bureaucracy. The most pessimistic view is offered by those respondents who live in large cities (more than 250,000 inhabitants) where corruption phenomena are more rooted than in smaller and rural communities.

\footnotetext{
${ }^{4}$ This is why Figure 2 does not report the position of those modalities and countries that collapse in the center of the two axes.
} 
The second point that we want to stress is that in Italian Southern regions, such as Campania, Puglia and Basilicata, citizens appear reticent or reluctant to express an opinion on this topic. In Calabria and Sardinia instead respondents refer to corruption as a problem that affected every-day life in the past. This is presumably due to the strict connection between the phenomena of corruption and organized crime. Criminal organizations in fact rely on different forms of corruption to obtain privileged solutions for their affairs and boost their illicit activities (Della Porta and Vannucci 1999; Calderoni and Caneppele 2009; Gounev and Bezlov 2010). Therefore, in Southern Italy, where organized crime is particularly rooted, citizens avoid to express their opinion on the problem of corruption or to minimize its spread. This attitude increases the difficulty in monitoring corruption and may be one of the reasons why national statistics show a decline in reported corruption crimes (Dallara 2013).

The Eurobarometer also allows us to investigate the perceptions of the Italian citizens on the spread of corruption within EU institutions. Figure 3 plots four bar charts. The two graphs in the upper side of the figure look only at the opinions of the Italian citizens. The graph on the left shows the percentage of Italian citizens which are totally agree or fairly agree with the statements affirming that there is corruption within national (CORR_NATIONAL) and EU institutions (CORR_EU), respectively. ${ }^{5}$ The graph on the right instead shows the percentage of respondents who think that national and EU institutions are corrupt in three different Italian sub-areas: "North" (Valle d'Aosta, Piemonte, Liguria, Lombardia, Veneto, Trentino Alto Adige, Friuli Venezia Giulia, Emilia Romagna), “Center” (Toscana, Marche, Umbria, Lazio) and "South”

\footnotetext{
${ }^{5}$ The exact wording of the question is the following: "Could you please tell me whether you totally agree, tend to agree, tend to disagree, totally disagree with the statement? 'There is corruption within the national institutions of your country/the institutions of the EU,'.
} 
(Abruzzo, Molise, Campania, Calabria, Basilicata, Puglia, Sicilia, Sardegna). ${ }^{6}$ The two graphs in the lower part of Figure 3 looks instead at the citizens of all the twenty-seven EU member states. The bar chart on the left reports the percentage of European citizens who affirm that there is corruption within their domestic national institutions and EU institutions, whereas the graph on the right subdivided the sample of respondents in three sub-areas according the their country. "North EU" includes the north continental countries, the Scandinavian countires, United Kingdom and Ireland, "South EU" includes those countries that overlook the Mediterranean sea (Portugal, Spain, France, Italy, Greece, Cyprus, Malta) and "East EU" includes the ten post-communist countries of Eastern Europe.

Figure 3 about here

Although the percentage of Italian citizens who think that there is corruption within EU institutions is slightly lower if compared with the domestic national level, more than $80 \%$ of respondents evaluate EU as well as domestic institutions as corrupt. Looking at the regional differences in Italy it is worth noting that in the Southern regions the percentage of citizens who think that there is corruption within national institutions is lower than in Northern and Center regions. This lower percentage can be probably explained with the connections between corruption and organized crime that we have discussed above. In these regions citizens tend to minimize the spread of corruption or

\footnotetext{
${ }^{6}$ Given the low number of respondents for each Italian region it is not possible to analyze the inter- and intra-regional differences in the opinion on corruption and the role played by the European Union. This is why we have preferred to aggregate respondents coming from neighbouring regions and analyze the differences in the three main Italian sub-areas.
} 
to avoid to express an opinion on it. Nevertheless, the three sub-areas do not present significant differences in the percentage of citizens who consider EU institutions as corrupt.

The same scenario depicted in Italy is present if we look at the respondents of all the twenty-seven member states, and the gap between the EU and the domestic level disappears. The Pearson index of correlation between the perceived level of corruption within national and EU institutions is $r=.63$ in Italy and $r=.55$ in all the twenty-seven EU member states. Regarding the regional differences in the EU it is worth noting that whereas Southern and Eastern Europe show the same pattern present in Italy, in which citizens perceive less corruption within EU institutions than in domestic ones, Northern Europe presents exactly the opposite situation. In Scandinavian and northern continental European member states, which are far less corrupt than the rest of Europe, citizens perceive a more widespread corruption within EU institutions than at the domestic national level. While the percentage of citizens perceiving the presence of corruption at the domestic level in Northern Europe is much lower than in the Southern and Eastern Europe (about $70 \%$ against about $90 \%$ ), the percentage of those perceiving corruption within EU institutions is the same.

Moreover, relying on Eurobarometer data we can assess which is the opinion of the Italian and the European citizens regarding a potential beneficial role of the European Union in contrasting corruption. Among the questions present in the Euobarometer there is one which assumes particular relevance for the purpose of the present analysis, because allows us to measure the citizens' trust in EU institutions in providing a solution for the problem of corruption. The exact wording of the statement is the following: "Imagine that you have been a victim in a particular corruption case, and you want to complain about it. Which institutions/body would you trust most to 
provide a solution for your case?". Among the potential answers there is the European Union institutions.

Figure 4 about here

Figure 4 plots the same kind of graphs already shown in Figure 3. However, here the percentage of citizens who consider their national institutions as corrupt (CORR_NATIONAL) is compared to the percentage of respondents who trust EU institutions to provide a solution for a corruption case (EU_TRUST). The two bar charts in the upper part of the figure reports the opinions expressed by the citizens of Italy and of the Northern, Center and Southern regions, respectively. On the contrary, the two bar charts in the lower part of the figure display the opinion of the respondents of all the twenty-seven EU member states and of the Northern, Southern and Eastern Europe. The scenario depicted by the opinions of the Italian citizens is pretty the same of the one related to the opinions expressed by the citizens of all the twenty-seven member states. While more than $80 \%$ of Italians think that EU institutions are corrupt, only $8.5 \%$ of them address EU institutions to complain about a specific case of corruption. This percentage grows up to $10 \%$ if we consider the citizens of all the twenty-seven countries. Looking at the regional differences in Italy, we can easily note that, though a different level of CORR_NATIONAL, Northern and Southern regions displays about the same percentage of people who trust EU for providing a good solution for a corruption case. On the contrary, center Italy, though displays a higher percentage of citizens who think that Italian institutions are corrupt, shows the lowest percentage of repondents who trust EU. 
However, the differences among the respondents' opinion of the three sub-areas of the European Union display a different scenario. Although the pairwise correlation between the perceived level of corruption in the domestic national institutions and the trust in the European Union in providing a solution for corruption cases is only $\mathrm{r}=.07$, this graph indicates that on average citizens' trust in EU is higher in those countries in which citizens perceive national institutions as more corrupt. As we can note, the percentage of respondents who trust EU institutions to provide a solution for a corruption case is higher in Eastern European countries where citizens perceive their national instituions as corrupt. On the contrary, this percentage is lower in Northern EU member states where citizens perceive far less corruption within their domestic institutions.

On the basis of this preliminary descriptive analysis the rest of the paper investigates which is the relationship between the perceptions of the Italians of the spread of corruption in their country and their opinions on the presence of corruption within EU institutions as well as on the role played by the European Union in providing a good solution for a corruption case.

\section{Theoretical Framework}

The literature offers different families of explanation of the mass public opinion on European Union and, in particular, the process of EU integration. ${ }^{7}$ On one side, a broad stream of literature explains citizens attitudes toward EU relying on utilitarian approaches based on a calculus of economic costs and benefits (Gabel 1998a; 1998b). According to this approach, citizens motivate their attitudes toward EU on the basis of

\footnotetext{
${ }^{7}$ For a more complete review of the theoretical approaches in studying public support toward EU see, among others (Gabel 1998a; 1998b) and (Serricchio 2010).
} 
an evaluation of the economic consequences for themselves and for the groups to which they belong.

On the other side, a second group of theories look at non-utilitarian factors to explain public support for EU. Among them, cognitive mobilization argues that high level of education, political awareness and well-developed skills in political communication favor pro-EU attitudes (Inglehart 1970; Janssen 1991). Other more recent studies investigate how social identities, and, above all, national identities, constrain support for European Union. Carey (2002) and McLaren (2002) argue that a strong national (and sub-national) identity is negatively related with citizens' support of European integration. A third perspective argues that public attitudes toward EU are guided by the domestic national context. Hooghe and Marks (2005), drawing on cognitive and social psychology, provide evidence that the effects of economic calculation and community membership are mediated by domestic ideology and political organizations. Other scholars focuses instead on the citizens' confidence in domestic institutions, the quality of national governance and the democratic performance as main determinants of their support toward EU integration (Anderson 1998; Sanchez-Cuenca 2000).

To investigate the opinion of the Italian citizens about the relationship between corruption and European Union we rely on this last theoretical framework, which motivates citizens attitudes toward EU institutions with the domestic national performance. More precisely, we postulate a strong relationship between Italian citizens' perceptions of corruption in their national institutions and their opinions on the spread of corruption within EU institutions as well as the role of EU in contrasting corruption. In other words, the Italian citizens' opinions on the phenomenon of 
corruption in the European Union is essentially guided by their perceptions at the domestic, above all national, level.

We advance two apparently alternative hypotheses on the relationship between corruption in national institutions and European Union. The first hypothesis looks at corruption within national institutions as the main determinants of the Italians perceptions of corruption at the EU level and postulates a positive effect. The first hypothesis is the following:

H1: the more the citizens perceive a widespread corruption within their domestic national institutions, the more they perceive EU institutions as corrupt.

As evidenced by Anderson (1998), citizens consider the performance of the domestic context as a "proxy" to determine their opinion about European Union. The assumption is that people are not well informed about many aspects of the European Union and are not aware about the complex process of decision making which involves EU institutions. As a consequence, we expect that citizens fill their knowledge gap by using proxies of the domestic national institutional context. In other words, citizens' attitudes toward European Union basically reflect more extensively developed political beliefs that derive from their experience with domestic political reality (Anderson 1998). Therefore, since Italians do not know the real spread of corruption within EU institution, in expressing their opinion, they rely on their more firmly held perceptions of corruption in the national context. Their opinions at the supranational level should be drawn by their perceptions at the domestic national level.

The second hypothesis also postulates a direct connection between citizens' opinions of the domestic national institutions performance and their attitudes toward the 
role played by EU institutions in contrasting corruption. However, contrary to $\mathrm{H}_{1}$, the second hypothesis presumes that this relationship has a negative sign. More precisely:

H2: the more the citizens perceive a widespread corruption in their domestic national institutions, the more they trust EU institutions to provide a solution for a case of corruption.

This hypothesis reflects a sort of "substitution mechanism" according to which citizens who express a negative opinion on the domestic national system performance tend to develop strong pro-EU attitudes (Sanchez-Cuenca 2000; Bellucci et al. 2012). As Sanchez-Cuenca (2000) argued, citizens of a state plagued by corruption and weak institutions may find a solution in the EU. This because they come to the conclusion that they have little to lose by opting for "more Europe". Therefore, those citizens that perceive Italian institutions as widely corrupt tend to trust more EU because they think that a more active role of EU institutions can contribute to find good solutions for specific corruption cases.

The two hypotheses may be seen as alternative because the sign of the relationship between the opinions on the domestic national context and the attitudes toward EU institutions is the opposite in the two. Nevertheless, this is not necessarily true. The two hypotheses may be both confirmed by the empirical analysis because they presume a different citizens' idea of the European Union. European citizens may perceive EU as a supranational polity characterized by multi-level government. Considering that they are not aware of the real decision-making process at the EU level, they tend to consider the decisions taken by EU as the result of a bargaining process among the representatives of different countries. Therefore, if citizens think that their 
home country representatives are corrupt, they will also perceive EU institutions as corrupt. This vision obviously prevail in the first hypothesis.

However, respondents may perceive European Union in more impersonal terms, namely as an institutional body that goes beyond the mere aggregation of the different member states representatives. According to this vision, if citizens perceive that their home country politicians extract private financial gain from illicit interactions, they will not think that these politicians have some incentives in contrasting corruption. Instead, only an external imposition may actively prevent and fight corruption. This vision underlies the second hypothesis and is partially captured by EU_TRUST that is used as dependent variable to test $\mathrm{H}_{2}$. As we have already seen, EU_TRUST does not measure a general trust in European Union in fighting corruption of the member states' domestic national institutions. It rather measures if a citizen, that have experienced a case of corruption and want to complain about it, would trust EU institutions (for instance an unelected body as the EU Court of Justice) more than other national and international bodies to provide a solution for his/her case.

\section{Data and Variables}

\section{Dependent Variables}

The dependent variables used in the multivariate analysis are CORR_EU and EU_TRUST. In the second section in which we have performed the descriptive analysis we have introduced these two variables presenting also the Eurobarometer questions from which responses they are developed. To test the validity of $\mathrm{H}_{1}$ we use CORR_EU as dependent variable. This is a four-points ordinal variable which measures the citizens' perceptions of the presence of corruption within EU institutions. To build CORR_EU we reverse the original scale so that higher values correspond with higher 
perceived levels of corruption (1 "totally disagree", 2 "tend to disagree", 3 "tend to agree", 4 “totally agree").

The dependent variable used to test the validity of $\mathrm{H}_{2}$ is EU_TRUST, which measures the citizens' trust in the EU institutions to provide a solution for a case of corruption. EU_TRUST is a dummy variable which assumes value of 1 in case of respondents that trust EU and 0 otherwise.

\section{Explanatory Factors}

According to the theoretical framework adopted, the main explanatory factor of the citizens perception of corruption within EU institutions and their trust in EU to provide a solution for the corruption problem is the level of corruption they perceive at the domestic national level. We operationalize it with an indicator that measures the citizens' perceptions of the presence of corruption in national institutions (CORR_NATIONAL).CORR_NATIONAL is a four-points ordinal variable and presents the same scale of CORR_EU: from 1 (totally disagree with the statement affirming there is corruption in national institutions) to 4 (totally agree). We control the effect of CORR_NATIONAL for the impact of an objective measure of corruption which refers to the actual citizens' experience with bribes (CORR_EXP) rather than to perceptions. More precisely, it is developed based on the following question: "Over the last 12 months, has anyone in [COUNTRY] asked you, or expected you, to pay a bribe for his or her services?". CORR_EXP is a dummy variable assuming value of 1 if the respondent answers that he/she has experienced a case of corruption from any the proposed public officials, and 0 otherwise. ${ }^{8}$

\footnotetext{
${ }^{8}$ It is worth noting that the term "objective" referred to experienced-based measures is used in the literature to distinguish these measures from the more "subjective" perceptions-based indicators.
} 
The impact of the corruption in the domestic context is also controlled for the effects of a series of alternative explanatory factors. The first control variables are two demographic indicators: AGE, that measures the age of respondents, and GENDER, that assumes value of 1 for female respondents and 0 for men. The next two variables can be considered indicators of the cognitive mobilization approach. EDUCATION is a categorical variable which measures the age of respondents when they stopped full-time education. INTERNET_USE is an indicator of the respondents' use of internet. It is an additive index that add three categorical indicators measuring the use of internet at home, on their place of work and somewhere else, respectively. Since each of the three indicators range from 1 (no internet access) to 7 (every day), INT_USE varies between 1 (lowest level) and 21 (highest level).

Other two variables refer to the respondents' social dimension. COMMUNITY is a categorical variable which indicates the size of the community in which respondents live (rural area; small-middle town; large town). SOC_LEVEL instead is developed based on the responses to a question asking citizens to self-place themselves on a scale ranging between 1 and 10, where 1 indicates the lowest level in the society and 10 the highest level.

Finally, we also include in the model two variables which indicate the respondents' working and economic situation. UNEMP is a dummy variable that assumes value 1 for unemployed citizens and 0 otherwise. ECON_DIFF instead is a categorical variable developed based on the responses on a question asking to citizens whether, during the last twelve months, they had difficulties in paying the bills at the end of the month. It ranges from 1 (almost never/never) to 3 (most of the time). methodological problems. 


\section{Empirical Results}

Table 1 reports the results of three models in which the dependent variable, CORR_EU, is regressed on the explanatory factors described above. Model 1 is our main model and is run only on Italian citizens, while the other two check the robustness of the results on larger samples. More precisely, Model 2 includes the citizens of the Mediterranean European countries and Model 3 includes the citizens of all the twenty-seven EU member states. The sub-sample composed by Mediterranean Europe has been chosen because countries such as Cyprus, Greece, Portugal and Spain experienced, like Italy, serious problems associated to the international economic and financial crisis. Given the ordinal nature of the dependent variable the three models are estimated using ordered logistic regressions with robust standard errors to control for the heteroskedasticity of the distribution. To take into account the hierarchical structure of the data, presenting individual observations nested in different countries, Model 2 and 3 are estimated with multilevel models. ${ }^{9}$ These last two models also include two control variables at the country-level: logGDP_CAPITA which measures the natural logarithm of the GDP per capita in 2009, and GDP_GROWTH which measures the average percentage growth of GDP per capita in the five years before the survey. There is a strong connection between economic development of countries and corruption. The inclusion of these two variables allow us to control if this connection affect citizens' perception of corruption.

\footnotetext{
${ }^{9}$ More precisely Model 2 and 3 are estimated using Generalized linear latent mixed models (gllamm). As further robustness check we have dichotomized the dependent variable and we have also estimated these two models using random-effects logistic regressions. The categories "totally agree" and "tend to agree" are dichotomized into the category "agree" (1), while the categories "tend to disagree" and "disagree" are dichotomized into the category disagree" $(0)$. The results of these models are very similar to the main ones and present the same levels of significance.
} 
Table 1 about here

The empirical results reported in Model 1 confirm $\mathrm{H}_{1}$. The more the Italian citizens perceive their domestic national institutions as corrupt, the more they think that corruption is also present at the EU level. The regression coefficient of CORR_NATIONAL is positive and highly significant The actual experience with corruption (CORR_EXP) instead is significantly but negatively related to the dependent variable. Italians who have been victim of corruption tend to perceive less corruption in EU institutions than those who have never suffered it. This result does not contradict our prediction because we hypothesize that citizens' perceptions of corruption in EU are drawn by their perception in the domestic national context. Considering that European Union is an institution normally perceived as distant from the citizens, it is implausible that an EU public agent asked to an Italian citizen to pay a bribe. It is much more plausible that they had been victim of bribe taking from national officials, such as policemen and local public agents. This lets citizens to perceive EU as an institution more free from pervasive corruption.

The main results obtained in Model 1 are also confirmed by the findings of Model 2 and 3. CORR_NATIONAL is positively and significantly associated with CORR_EU also in south European countries and in the twenty-seven EU member states, while CORR_EXP presents a negative sign. This result means that the perceptions of corruption in EU expressed by European citizens are guided, as well, by their perceptions of the performance of their national country's institutions. At the same time, even in larger sample, actual experiences with bribes instead are associated with less perceptions of corruption at the EU level. 
Among the alternative explanatory factors, only INTERNET_USE is significantly correlated with the dependent variable in all the three models tested. It always presents a negative sign. Respondents that more frequently use internet, which are presumably more informed and more aware of the functioning of the European Union, perceive less corruption in EU institutions. Moreover, it is worth noting that internet use is particularly frequent especially among younger respondents who, according to the cognitive mobilization argument, tend to be more supportive of the EU (Inglehart 1970). The effect played by AGE instead is less clear. Whereas in Italy it is negatively associated with corruption, in all the twenty-seven member states the regression coefficient of AGE presents a positive sign. Although in Model 1 none of the other control variables present a significant coefficient, ECON_DIFF is positively and significantly related to the dependent variable in both Model 2 and 3. This result indicates that the more the respondents have difficulties in paying bills, the more they perceive EU institutions as more corrupt. Finally, in Model 3 logGDP_CAPITA presents a positive and significant regression coefficient. This means that, on average, citizens who live in countries characterized by a higher economic performance and higher levels of GPD per capita tend to perceive a more widespread corruption within EU institutions.

Table 2 presents three regression models which analyze the determinants of the citizens' trust in the European Union in providing a solution for a specific corruption case (EU_TRUST). As we did in the previous analysis, the first model reported in the table (Model 4) tests the validity of $\mathrm{H}_{2}$ only among Italian citizens, while Model 5 and 6 check the robustness of the result among the citizens of the South European countries and all the twenty-seven member states, respectively. Given the dichotomous nature of the dependent variable (EU_TRUST), Model 4 reports the results of a logistic 
regression, while Model 5 and 6 are estimated with multilevel random-effects logistic regressions. ${ }^{10}$ The explanatory factors are the same tested in the previous three models with the addition of the variable measuring the perceived corruption within EU institutions (CORR_EU).

Table 2 around here

As we can see from the results reported in Model 4, CORR_NATIONAL is positively and significantly correlated with the dependent variable. Therefore, as hypothesized in $\mathrm{H}_{2}$, the more the Italian citizens perceive their domestic national institutions as corrupt, the more they trust EU institutions to provide a solution for a potential case of corruption. $\mathrm{H}_{2}$ is also confirmed by the result associated with the objective indicator of corruption, which measures the Italians' actual experience with bribes. In fact, the regression coefficient of CORR_EXP is positively and significantly associated with EU_TRUST. Those citizens that had been victim of corruption trust European Union to provide a solution for their case.

On the contrary, none of the other variables tested are significantly correlated with EU_TRUST, though, as presumable, the regression coefficient of CORR_EU presents a negative sign.

The validity of $\mathrm{H} 2$ is reaffirmed by the results obtained in Model 5 and 6 . Even in larger samples of countries CORR_NATIONAL, as well as CORR_EXP, are positively and significantly correlated with EU_TRUST. Therefore, the more the citizens of the EU member states perceive their domestic national institutions as corrupt,

\footnotetext{
${ }^{10} \mathrm{We}$ have run an Hausman test and the result obtained suggested us to apply a random-effect regression model in respect to a fixed-effects one.
} 
the more they trust EU to prevent and fight corruption. Moreover, especially in Model 6 , the regression coefficients of other control variables reach the conventional standard significance levels and present a sign that goes in the expected direction. Here CORR_EU is negatively and significantly related with the dependent variable. On the contrary, INTERNET_USE, COMMUNITY and GDP_GROWTH are positively and significantly associated with EU_TRUST. In other words, citizens who more frequently use internet and live in larger cities and in more economically developed countries express higher confidence in an active role of the European Union in finding a solution for a corruption case. On the contrary, as confirmed by the negative regression coefficient of AGE and GENDER, in Europe older people and females tend to trust less EU institutions for providing a solution for the problem of corruption.

\section{Conclusions}

The present study aims to investigate the relationship between the Italian citizens' perceptions of corruption in the domestic national context and their attitudes toward European Union. A broad literature has analyzed the detrimental effects of corruption on political and economic performance. It is unanimously recognized by the experts that corruption is one of the major problems that affect Italian institutions. A descriptive analysis shows that the scenario depicted by the experts is confirmed by the perceptions expressed by the Italian citizens. More than $80 \%$ of the Italian respondents surveyed by the Eurobarometer 72.2 of 2009 perceive their national institutions as corrupt. Moreover, it emerges that Italian, as well as European, citizens do not perceive European Union as immune by corruption. While more than $80 \%$ of the Italian citizens perceive EU institutions as corrupt, only less than 9\% trust the European Union for providing a solution for a specific corruption case. 
Following a theoretical approach which argues that citizens attitude toward EU are mainly driven by their evaluation of the domestic national institutions' performance, we advance two alternative, though not necessarily contrasting, hypotheses. The first postulates that the more the citizens perceive Italian national institutions as corrupt, the more they perceive the presence of corruption at the EU level. The second instead postulates that the more the citizens perceive the presence of corruption in their domestic national institutions, the more they trust the European Union for providing a solution for the problem of corruption. The results of a multivariate analysis confirm the validity of both the two hypotheses highlighting that Italian citizens' attitudes on the presence of corruption in the European Union and its role in providing a solution for a potential corruption case are guided by their perceptions of corruption in the domestic national context. The results obtained for Italy are also confirmed if we look at the entire sample composed by all the twenty-seven EU member states.

Nevertheless, the main findings obtained in the present analysis may be improved in several ways. First, the same analysis conducted here can be performed in other European Union member states. If the relationship between the perceptions of corruption at the domestic and EU level was also confirmed analyzing the citizens of other countries, the main findings obtained here would be more robust. Second, further research may test the hypotheses advanced above using different dependent variables which specify different aspects of the citizens attitudes toward corruption in the European Union. Finally, further analyses should benefit by the inclusion of more alternative explanatory factors, such as the citizens' ideological preferences, political attitudes and voting behavior, for which data were not available here. These variables allow scholars to test the validity of other theoretical frameworks about the citizens' attitudes toward EU. 


\section{References}

Anderson, C. J. (1998) When in doubt, use proxies. Attitudes toward domestic politics and support for European integration, Comparative Political Studies 31(5), pp. $569-601$

Anderson, C.J. and Y. Tverdova (2003) Corruption, political allegiances and attitudes toward government in contemporary democracies, American Journal of Political Science 47(1), pp. 91-109.

Bellucci, P., D. Sanders and F. Serricchio (2012) Explaining European identity, in: D. Sanders, P. Bellucci, G. Toka \& M. Torcal (Eds) The Europeanization of National Polities? Citizenship and support in a post-enlargement Union, pp. 6190 (Oxford, UK: Oxford University Press).

Benzécri, J.P. (1965) Analyse factorielle des proximités II, Publications de l'Istitute de Statistique de l'Université de Paris, n. 14.

Benzécri, J.P. (1976) L'Analyse des Données II. Correspondances, $2^{\text {nd }}$ ed. (Paris: Dunod).

Calderoni, F. and S. Caneppele (Eds.) (2009) La geografia criminale degli appalti. Le infiltrazioni della criminalità organizzata negli apparati pubblici nel Sud Italia (Milano: Franco Angeli).

Carey, S. (2002) Undivided loyalty: Is national identity an obstacle to European integration?, European Union Politics, 12(3), pp. 387-413.

Chang, E.C.C., M.A. Golden and S.J. Hill (2010) Legislative Malfeasance and Political Accountability, World Politics, 62(2), pp. 177-220. 
Clausen, B., A. Kraay and Z. Nyiri (2011) Corruption and Confidence in Public Institutions: Evidence from a Global Survey, The World Bank Economic Review, 25(2), pp. 212-49.

Corbetta, P. and E. Gualmini (Eds.) (2013) Il Partito di Grillo (Bologna: Il Mulino).

Dallara, C. (2013) Corruzione, in: L. Morlino, D. Piana, F. Raniolo (Eds), La qualità della democrazia in Italia 1992-2012, pp. 217-232 (Bologna: Il Mulino).

Della Porta, D. and A. Vannucci (1999) Corrupt Exchanges: Actors, resources, and mechanisms of political corruption (New York: Aldine De Gruyer).

Gabel, M. (1998a) Public support for European integration: An empirical test of five theories, The Journal of Politics, 60(2), pp. 333-54.

Gabel, M. (1998b) Interests and Integration: Market Liberalization, Public Opinion and European Union (Ann Arbor, MI: University of Michigan Press).

Giampaolino, L. (2011) Misure e stime della corruzione: una sfida (im)possibile? Invited talk by the President of the Italian Corte dei Conti held at Scuola Superiore della Pubblica Amministrazione, Roma, Italy. Available at: http://www.corteconti.it/export/sites/portalecdc/_documenti/chi_siamo/president e_giampaolino/3_febbraio_2011_intervento_presidente_giampaolino.pdf (accessed 27 June 2013).

Gounev, P. and T. Bezlov (2010) Examining the links between organized crime and corruption (Luxembourg: Center for the Study of Democracy).

Hooghe, L. and G. Marks (2005) Calculation, community and cues: Public opinion on European integration, European Union Politics, 6(4), pp. 419-43. 
Kaufmann, D., A. Kraay and P. Zoido-Lobatòn (1999) Governance matters, World Bank policy research working paper n. 2196, The World Bank, Washington DC.

Knack, S. and P. Keefer (1995) Institutions and economic performance: Cross-country tests using alternative institutional measures, Economics \& Politics, 7(3), pp. 207-27.

Inglehart, R. (1970) Cognitive mobilization and European identity, Comparative Politics, 3(1), pp. 45-70.

Janssen, J. (1991) Postmaterialism, cognitive mobilization and public support to European integration, British Journal of Political Science, 21(4), pp. 443-68.

Mauro, P. (1995) Corruption and growth, The Quarterly Journal of Economics, 110(3), pp. 681-712.

McLaren, L. M. (2002) Public support for European Union: Cost/benefit analysis or perceived cultural threat?, The Journal of Politics, 64(2), pp. 551-66.

Memoli, V. (2013) Responsiveness, in: L. Morlino, D. Piana \& F. Raniolo (Eds.) La qualità della democrazia in Italia 1992-2012, pp. 233-249 (Bologna: Il Mulino).

Mishler, W. and R. Rose (2001) What are the origins of political trust? Testing institutional and cultural theories in post-communist societies, Comparative Political Studies, 34(1), pp. 30-62.

Morlino, L. (2004) What is a 'good' democracy?, Democratization, 11(5), pp. 10-32.

Rigamonti, V. (2013) Fighting corruption in Italy is an uphill struggle. Transparency International Blog. Available at: 
http://blog.transparency.org/2013/02/18/fighting-corruption-in-italy-is-an-uphillstruggle/ (accessed 27 June 2013).

Sanchez-Cuenca, I. (2000) The political basis of support for European integration, European Union Politics, 1(2), pp. 147-171.

Serricchio, F. (2010) Gli italiani e l'Europa: Un rapporto che muta tra benefici, “institutional proxies” e identità nazionale, Rivista Italiana di Scienza Politica, 40(3), pp. 371-96.

Vannucci, S. (2009). The Controversial Legacy of 'Mani Pulite': A Critical Analysis of Italian Corruption and Anti-Corruption Policies, Bulletin of Italian Politics, 1(2), pp. 233-64.

Zakaria, P. (2013) Is corruption an enemy of civil society? The case of Central and Eastern Europe, International Political Science Review, 34(4), pp. 351-71. 
Table 1. Determinants of the citizens' perceived level of corruption within EU institutions.

\begin{tabular}{|c|c|c|c|}
\hline $\begin{array}{l}\text { Dependent variable: } \\
\text { Corruption in EU }\end{array}$ & $\begin{array}{c}\text { Model 1 } \\
\text { (Italy) }\end{array}$ & $\begin{array}{c}\text { Model } 2 \\
\text { (South Europe) }\end{array}$ & $\begin{array}{c}\text { Model 3 } \\
\text { (European Union) } \\
\end{array}$ \\
\hline CORR_NATIONAL & $\begin{array}{l}2.3032 * * * \\
(.1755)\end{array}$ & $\begin{array}{l}2.6518 * * * \\
(.0637)\end{array}$ & $\begin{array}{c}2.2267 * * * \\
(.0266)\end{array}$ \\
\hline CORR_EXP & $\begin{array}{c}-.4870 * * \\
(.2037)\end{array}$ & $\begin{array}{l}-.1914 * \\
(.1011)\end{array}$ & $\begin{array}{c}-.1336 * * * \\
(.0479)\end{array}$ \\
\hline AGE & $\begin{array}{c}-.0096 * * \\
(.0041)\end{array}$ & $\begin{array}{r}-.00009 \\
(.0020)\end{array}$ & $\begin{array}{c}.0059 * * * \\
(.0009)\end{array}$ \\
\hline GENDER & $\begin{array}{l}-.0824 \\
(.1399)\end{array}$ & $\begin{array}{c}.0588 \\
(.0631)\end{array}$ & $\begin{array}{l}-.0199 \\
(.0287)\end{array}$ \\
\hline EDUCATION & $\begin{array}{l}.0863 \\
(.0784)\end{array}$ & $\begin{array}{l}-.0178 \\
(.0370)\end{array}$ & $\begin{array}{c}.0175 \\
(.0166)\end{array}$ \\
\hline INTERNET_USE & $\begin{array}{c}-.0470 * * * \\
(.0165)\end{array}$ & $\begin{array}{c}-.0182 * * \\
(.0087)\end{array}$ & $\begin{array}{c}-.0080 * * \\
(.0040)\end{array}$ \\
\hline COMMUNITY & $\begin{array}{l}.0180 \\
(.1229)\end{array}$ & $\begin{array}{l}-.0800^{*} \\
(.0411)\end{array}$ & $\begin{array}{c}.0095 \\
(.0184)\end{array}$ \\
\hline SOC_LEVEL & $\begin{array}{l}.0430 \\
(.0564)\end{array}$ & $\begin{array}{l}-.0032 \\
(.0253)\end{array}$ & $\begin{array}{l}-.0118 \\
(.0105)\end{array}$ \\
\hline UNEMP & $\begin{array}{l}.2072 \\
(.3480)\end{array}$ & $\begin{array}{l}.0978 \\
(.1310)\end{array}$ & $\begin{array}{l}.0270 \\
(.0583)\end{array}$ \\
\hline ECON_DIFF & $\begin{array}{l}.1109 \\
(.1180)\end{array}$ & $\begin{array}{l}.0923^{*} \\
(.0509)\end{array}$ & $\begin{array}{c}.1073 * * * \\
(.0246)\end{array}$ \\
\hline logGDP_CAPITA & & $\begin{array}{l}.2307 \\
(.2551)\end{array}$ & $\begin{array}{c}.7793 * * * \\
(.1481)\end{array}$ \\
\hline GDP_GROWTH & & $\begin{array}{l}-.0717 \\
(.0746)\end{array}$ & $\begin{array}{l}-.0504 \\
(.0626)\end{array}$ \\
\hline Cut point 1 & $\begin{array}{l}2.3074 \\
(.7768)\end{array}$ & $\begin{array}{c}5.3421 \\
(2.6834)\end{array}$ & $\begin{array}{l}10.0611 \\
(1.6403)\end{array}$ \\
\hline Cut point 2 & $\begin{array}{l}5.1796 \\
(.7580)\end{array}$ & $\begin{array}{c}8.2752 \\
(2.6836)\end{array}$ & $\begin{array}{l}12.8979 \\
(1.6408)\end{array}$ \\
\hline Cut point 3 & $\begin{array}{l}8.3135 \\
(.8365)\end{array}$ & $\begin{array}{l}11.8200 \\
(2.6872)\end{array}$ & $\begin{array}{l}16.1392 \\
(1.6424)\end{array}$ \\
\hline Observations & 816 & 4837 & 21393 \\
\hline Groups & - & 7 & 27 \\
\hline Log-likelihood & -683.5777 & -3617.0149 & -17581.071 \\
\hline
\end{tabular}

Notes: Robust standard errors in parentheses. Model 1 is estimated using an ordered logistic regression, while Model 2 and 3 are estimated using generalized linear latent and mixed models, using country as group variable. $* \mathrm{p}<.1 ; * * \mathrm{p}<.05 ; * * * \mathrm{p}<.01$. 
Table 2. Determinants of the citizens' trust in EU institutions in providing a solution for a specific corruption case.

\begin{tabular}{|c|c|c|c|}
\hline $\begin{array}{l}\text { Dependent variable: } \\
\text { Trust in EU }\end{array}$ & $\begin{array}{c}\text { Model } 4 \\
\text { (Italy) }\end{array}$ & $\begin{array}{c}\text { Model 5 } \\
\text { (South Europe) } \\
\end{array}$ & $\begin{array}{c}\text { Model 6 } \\
\text { (European Union) }\end{array}$ \\
\hline CORR_EU & $\begin{array}{l}-.0482 \\
(.2231)\end{array}$ & $\begin{array}{c}-.3639 * * * \\
(.0832)\end{array}$ & $\begin{array}{c}-.3746 * * * \\
(.0361)\end{array}$ \\
\hline CORR_NATIONAL & $\begin{array}{l}.7078 * * * \\
(.2687)\end{array}$ & $\begin{array}{c}.4007 * * * \\
(.1033)\end{array}$ & $\begin{array}{c}.3938 * * * \\
(.0431)\end{array}$ \\
\hline CORR_EXP & $\begin{array}{l}.8211 * * * \\
(.2687)\end{array}$ & $\begin{array}{l}.2774^{*} \\
(.1519)\end{array}$ & $\begin{array}{c}.2670 * * * \\
(.0653)\end{array}$ \\
\hline AGE & $\begin{array}{l}.0040 \\
(.0084)\end{array}$ & $\begin{array}{l}.0003 \\
(.0034)\end{array}$ & $\begin{array}{c}-.0079 * * * \\
(.0016)\end{array}$ \\
\hline GENDER & $\begin{array}{l}.0371 \\
(.2483)\end{array}$ & $\begin{array}{c}-.2972 * * * \\
(.1038)\end{array}$ & $\begin{array}{c}-.1750 * * * \\
(.0462)\end{array}$ \\
\hline EDUCATION & $\begin{array}{l}-.1935 \\
(.1417)\end{array}$ & $\begin{array}{l}-.0119 \\
(.0588)\end{array}$ & $\begin{array}{l}.0330 \\
(.0264)\end{array}$ \\
\hline INTERNET_USE & $\begin{array}{l}.0236 \\
(.0279)\end{array}$ & $\begin{array}{c}.0614 * * * \\
(.0668)\end{array}$ & $\begin{array}{c}.0296 * * * \\
(.0063)\end{array}$ \\
\hline COMMUNITY & $\begin{array}{l}.2102 \\
(.1831)\end{array}$ & $\begin{array}{l}.0418 \\
(.0668)\end{array}$ & $\begin{array}{l}.0764 * * \\
(.0297)\end{array}$ \\
\hline SOC_LEVEL & $\begin{array}{l}.0630 \\
(.1053)\end{array}$ & $\begin{array}{l}.0745^{*} \\
(.0405)\end{array}$ & $\begin{array}{l}.0255 \\
(.0168)\end{array}$ \\
\hline UNEMP & $\begin{array}{l}-1.1614 \\
(1.0206)\end{array}$ & $\begin{array}{l}-.2630 \\
(.2573)\end{array}$ & $\begin{array}{l}.0026 \\
(.0899)\end{array}$ \\
\hline ECON_DIFF & $\begin{array}{l}-.0339 \\
(.2111)\end{array}$ & $\begin{array}{l}-.0058 \\
(.0830)\end{array}$ & $\begin{array}{l}.0101 \\
(.0379)\end{array}$ \\
\hline logGDP_CAPITA & & $\begin{array}{l}-.0462 \\
(.5158)\end{array}$ & $\begin{array}{l}-.2427 \\
(.1823)\end{array}$ \\
\hline GDP_GROWTH & & $\begin{array}{c}.1547 \\
(.1488)\end{array}$ & $\begin{array}{l}.1563^{* *} \\
(.0686)\end{array}$ \\
\hline Constant & $\begin{array}{c}-5.2867 * * * \\
(1.4207)\end{array}$ & $\begin{array}{l}-2.8405 \\
(5.3848)\end{array}$ & $\begin{array}{l}-.4265 \\
(2.0031)\end{array}$ \\
\hline Rho & & $\begin{array}{l}.0221 \\
(.0153)\end{array}$ & $\begin{array}{c}.0324 \\
(.0100)\end{array}$ \\
\hline Observations & 816 & 4837 & 21393 \\
\hline Groups & - & 7 & 27 \\
\hline Log-likelihood & -238.0645 & -1391.7675 & -6670.8705 \\
\hline
\end{tabular}

Notes: Robust standard errors in parentheses. Model 1 is estimated using a logistic regression, while Model 5 and 6 are estimated using multilevel random-effects logistic regressions, using country as group variable. $* \mathrm{p}<.1 ; * * \mathrm{p}<.05 ; * * * \mathrm{p}<.01$. 


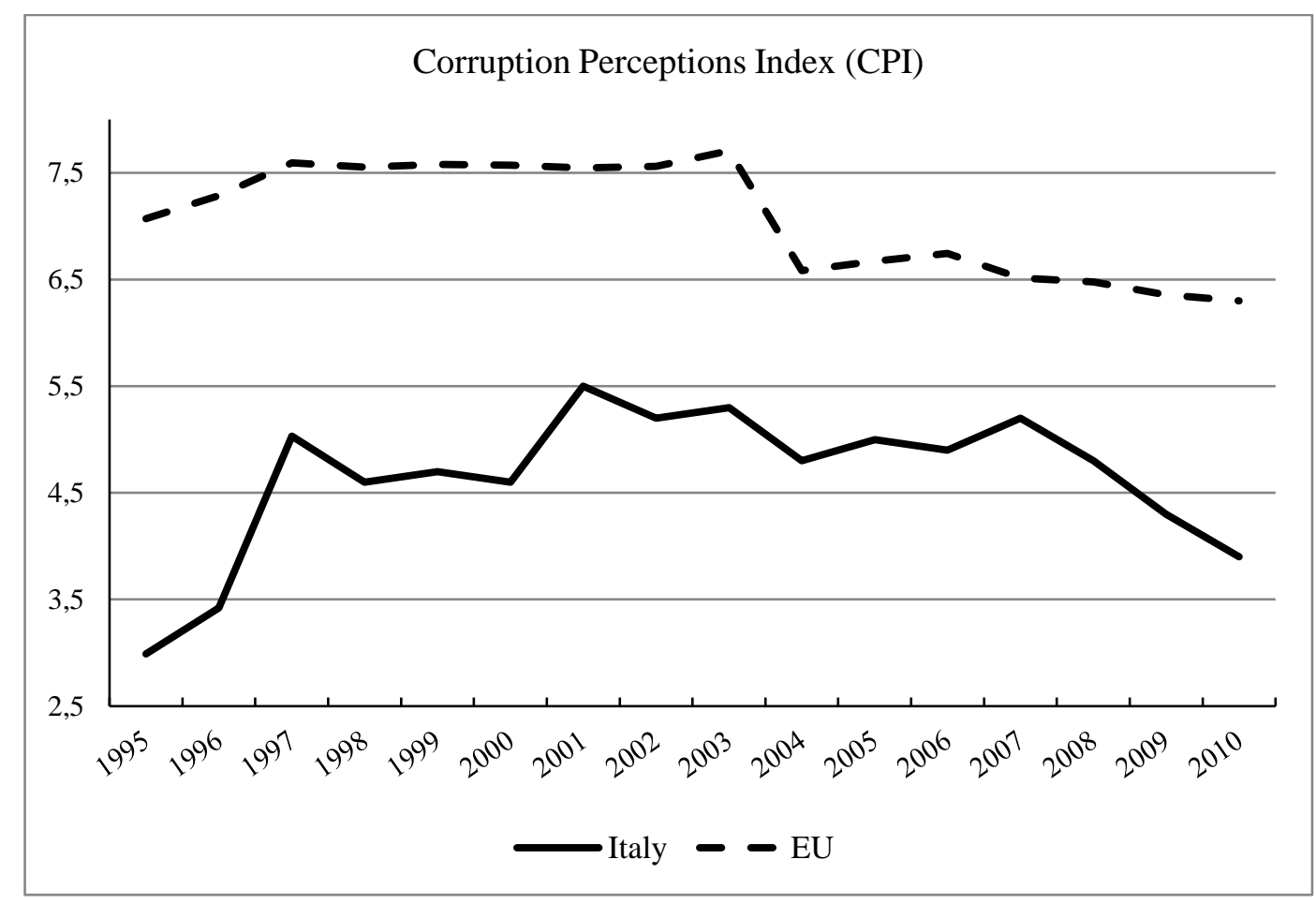

Figure 1. Experts' perceived corruption levels in EU (average level of the twenty-seven EU member states) and Italy.

Source: Corruption Perceptions Index (CPI). Transparency international. 


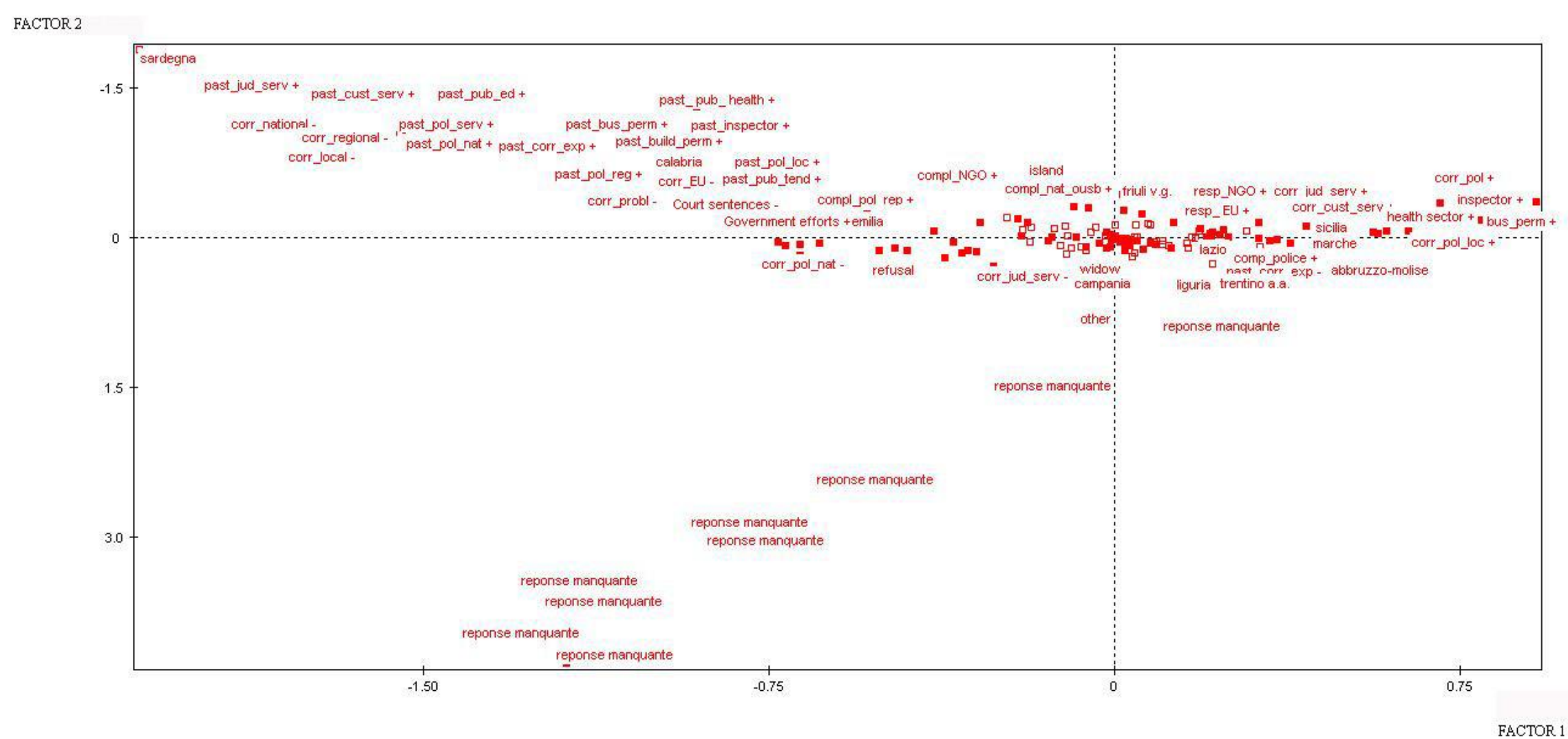

Figure 2. Opinions of the Italian citizens on different aspects of corruption in their country.

Source: Eurobarometer 72.2 (2009). 


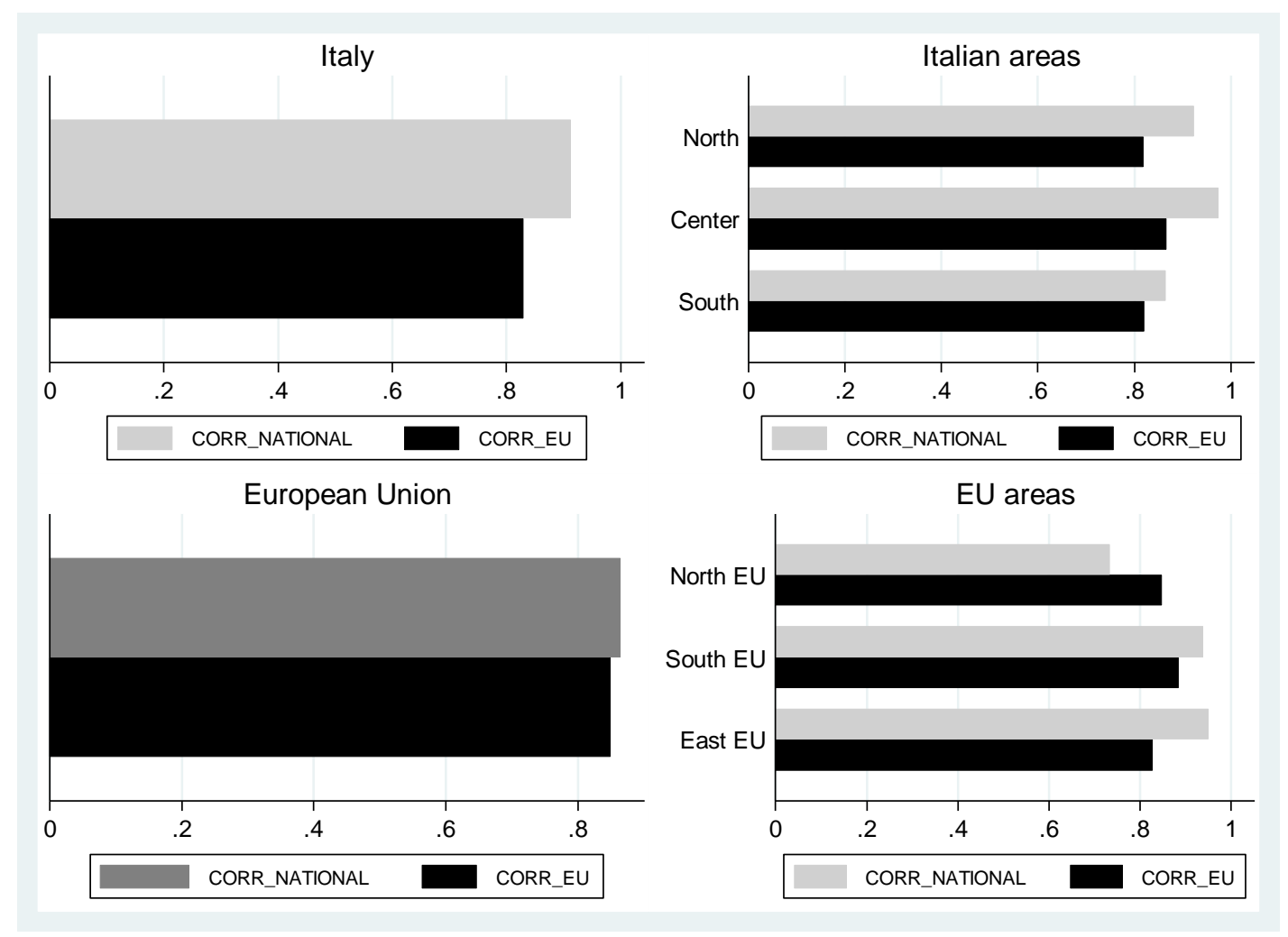

Figure 3. Graph bars of the citizens' perceptions of corruption at the domestic national and EU level.

Source: Eurobarometer 72.2 (2009). 

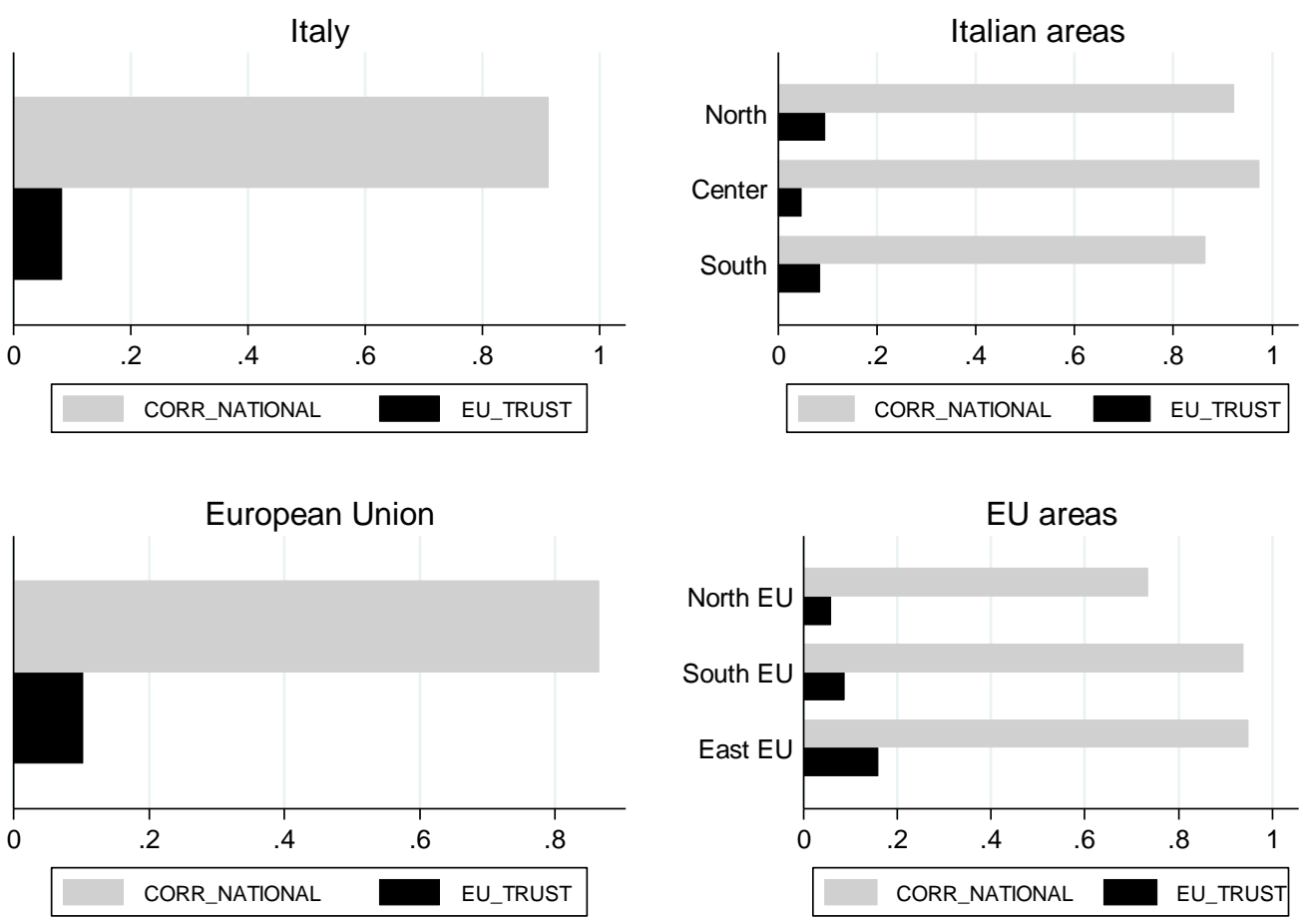

Figure 4. Graph bars of the citizens' perceptions of corruption in the domestic national context and the trust in EU institutions for providing a solution for corruption cases. Source: Eurobarometer 72.2 (2009). 